\title{
Quantitative Proteomic Analyses of Cerebrospinal Fluid Using iTRAQ in a Primate Model of Iron Deficiency Anemia
}

\author{
Stephanie M. Patton ${ }^{\mathrm{a}}$ Christopher L. Coe ${ }^{\mathrm{b}}$ Gabriele R. Lubach ${ }^{\mathrm{b}}$ \\ James R. Connor ${ }^{\text {a }}$ \\ a Penn State University College of Medicine, Hershey, Pa., and ${ }^{b}$ Harlow Center for Biological Psychology, \\ University of Wisconsin, Madison, Wisc., USA
}

\section{Key Words}

Prostaglandin-H2 D-isomerase $\cdot$ Fibronectin • $\alpha$-1-Antitrypsin • Toll-like receptor $8 \cdot$ Amyloid $\beta$ A4 protein $\cdot$ Cerebrospinal fluid $\cdot$ Anemia $\cdot$ Monkey

\begin{abstract}
Iron deficiency affects nearly 2 billion people worldwide, with pregnant women and young children being most severely impacted. Sustained anemia during the first year of life can cause cognitive, attention and motor deficits, which may persist despite iron supplementation. We conducted ITRAQ analyses on cerebrospinal fluid (CSF) from infant monkeys (Macaca mulatta) to identify differential protein expression associated with early iron deficiency. CSF was collected from 5 iron-sufficient and 8 iron-deficient anemic monkeys at weaning age (6-7 months) and again at 12-14 months. Despite consumption of iron-fortified food after weaning, which restored hematological indices into the normal range, expression of 5 proteins in the CSF remained altered. Most of the proteins identified are involved in neurite outgrowth, migration or synapse formation. The results reveal novel ways in which iron deficiency undermines brain growth and results in aberrant neuronal migration and connections. Taken together with gene expression data from rodent models
\end{abstract}

of iron deficiency, we conclude that significant alterations in neuroconnectivity occur in the iron-deficient brain, which may persist even after resolution of the hematological anemia. The compromised brain infrastructure could account for observations of behavioral deficits in children during and after the period of anemia.

Copyright $\odot 2012$ S. Karger AG, Base

\section{Introduction}

Iron deficiency affects nearly 2 billion people worldwide [1], with pregnant women and young children most severely impacted due to the increased iron demands associated with these periods. In the USA, infants from low socioeconomic status, especially African-American infants, are particularly at risk for developing iron deficiency anemia (IDA) [2-4].

It has been shown that sustained anemia during the first year of life can cause cognitive, attention and motor deficits, which may persist even after receiving iron supplementation [5-7]. These children were also found to evince differences in the socioemotional domain, including being more fearful, wary, unhappy and fatigued [8]. The findings indicate that IDA not only has immedi-

\section{KARGER}

Fax +4161306 1234

E-Mail karger@karger.ch

www.karger.com (c) 2012 S. Karger AG, Basel

0378-5866/12/0344-0354\$38.00/0

Accessible online at:

www.karger.com/dne
Stephanie M. Patton, $\mathrm{PhD}$

Penn State University, Milton S. Hershey Medical Center, Department of Neurosurgery 500 University Drive, Mail Code H110

Hershey, PA 17033 (USA)

E-Mailsmp11@psu.edu 
ate metabolic effects but appears to undermine the normal development of the brain and can disrupt the regulatory set points for several important neurotransmitters [9].

Iron deficiency during this period of rapid neural development has multiple effects on the maturing biochemistry, bioenergetics and morphology of the central nervous system (CNS). Rodent studies have demonstrated that iron deficiency during the nursing period results in decreased dendritic arborization, in association with fewer and less complex interneuronal connections (i.e. decreased synaptogenesis) [10-12]. In addition, the locations and activity of oligodendrocytes in iron-deficient rat pups are altered, resulting in an abnormal composition of white matter and less myelination [13, 14]. Iron is also critical for the biosynthesis and catabolism of the monoaminergic neurotransmitters, impacting both dopamine and norepinephrine. Impairments of motor control, dysregulation of the sleep-wake cycle and poorer learning and memory functions have all been linked to these changes in monoamine levels [7]. Finally, in addition to the traditional findings of disturbed oxidative metabolism and glucose homeostasis [15], recent studies using more sophisticated approaches, such as magnetic resonance spectroscopy, have identified numerous metabolites that are altered in important brain regions, including the striatum and hippocampus [11, 16-18].

There is a continuing need for better biomarkers to enable more systematic assessment of brain iron status during development and to evaluate intervention strategies that attempt to replenish brain iron and remedy the associated neurological deficits. Although serum would be the most convenient source for routine, noninvasive testing, cerebrospinal fluid (CSF) is more likely to provide an accurate reflection of depleted iron stores in the brain [19-21]. Several recent studies have documented that there is a selective prioritization and partitioning of iron across different tissues in the anemic state, and thus hematological indices do not sensitively reflect the full extent of the CNS depletion [19]. One other advantage of CSF as the biological medium for the proteomic approach used in the current research is that CSF is sequestered behind both the blood-brain and brain-CSF barriers. This isolation permits the identification of proteins derived from the parenchyma and specific to iron deficiency within the CNS. Moreover, the CSF used in this project was acquired via taps at the cervical level rather than from the lumbar region, thereby ensuring that the specimen was obtained primarily from the brain. This location also permitted the analyses to be unaffected by the rostral-to-caudal diffusion gradient in the intrathecal compartment that has been detected for a number of compounds with lumbar taps [22].

In the present study, a well-characterized nonhuman primate model of infancy anemia was employed to generate the iron-sufficient (IS) and iron-deficient subjects [23]. CSF was collected at this time and then again following the normalization of iron status at 1 year of age, due to consumption of an iron-fortified diet. An iTRAQ analysis of the CSF at both time points was utilized to test the hypothesis that the protein profile would be abnormal in the iron-deficient infants and that certain proteins would then remain altered, persisting for several months after the normalization of hematological parameters. Moreover, the analyses provided the opportunity to identify novel proteins that might account for the lingering neural and behavioral deficits that persist after repletion.

\section{Materials and Methods}

\section{Animals}

The subjects were 13 infant rhesus monkeys (Macaca mulatta) born and reared under standardized conditions at the Harlow Primate Laboratory. They were from full-term, singleton pregnancies with normal vaginal deliveries. The focus was on potential biomarkers in the CSF from these offspring (5 IS and 8 IDA), which were determined at weaning age (6-7 months) and then at 12-14 months of age, after they had been consuming solid food independent from the mother.

\section{Diet}

This primate model of infant anemia is generated by maintaining adult female monkeys on a controlled diet with moderate levels of iron fortification (225 mg Fe/ $\mathrm{kg}$ ) during pregnancy and lactation (Purina 5LFD). Approximately $20-40 \%$ of infant monkeys will typically become anemic when the dams consume this diet. The prevalence is comparable to that found by other laboratories previously with diets containing similar amounts of iron $[24,25]$. Ferrous sulfate was used to fortify the diet up to the desired level, and the concentration of other minerals and vitamins was also controlled. Once weaned by 7 months of age, the juvenile monkeys were fed the same diet. A small amount of supplemental fruit was provided in the afternoon as part of the environmental enrichment program, in keeping with federal regulations.

\section{Hematology and Iron Panel}

Small blood samples $(<4 \mathrm{ml})$ were obtained via femoral venipuncture to determine the infants' hematological and iron status. Results are presented for two red blood cell parameters with known clinical cutoffs for IDA in monkeys, i.e. mean corpuscular volume ( $<60 \mathrm{fl}$ for IDA) and hemoglobin ( $<11 \mathrm{~g} / \mathrm{dl}$ for IDA), as well as two other indices that were confirmatory of the categorization of an infant as either IS or IDA, i.e. the hematocrit and red blood cell distribution width. 


\section{CSF Collection}

CSF was collected when the monkeys were 6-7 and 12-14 months of age. Following rapid sedation with ketamine hydrochloride (15 mg/kg body weight), approximately $1.0 \mathrm{ml}$ of CSF was obtained via cervical puncture with a 25 -gauge needle and syringe and placed immediately on ice. CSF specimens were spun at low speed in a refrigerated centrifuge to remove any cellular contamination, aliquoted and stored at $-60^{\circ} \mathrm{C}$. All samples were collected between 09.30 and $11.00 \mathrm{~h}$.

\section{Experimental Design}

Experiment 1. CSF from 8 IDA infant monkeys was labeled as follows: pool 1 (equivalent protein amounts from 6- to 7-monthold monkeys ID1, ID2 and ID3), iTRAQ reagent 113; pool 2 (equivalent protein amounts from 6- to 7-month-old ID4, ID5 and ID6), iTRAQ reagent 114; 6-month-old ID7, iTRAQ reagent 115; 6-month-old ID8, iTRAQ reagent 116; pool 1 (equivalent protein amounts from 12-month-old ID1, ID2 and ID3), iTRAQ reagent 117; pool 2 (equivalent protein amounts from 12-monthold ID4, ID5 and ID6), iTRAQ reagent 118; 12-month-old ID7, iTRAQ reagent 119, and 12-month-old CS1 (an IS common sample used in both sets of experiments for comparison), iTRAQ reagent 121.

Experiment 2. CSF from 5 IS infant monkeys was labeled as follows: pool 1 (equivalent protein amounts from 6- to 7-monthold IS1 and IS2), iTRAQ reagent 113; pool 2 (equivalent protein amounts from 6- to 7-month-old IS3 and IS4), iTRAQ reagent 114; 6-month-old IS5, iTRAQ reagent 115; pool 1 (equivalent protein amounts from 12-month-old IS1 and IS2), iTRAQ reagent 116; pool 2 (equivalent protein amounts from 12-month-old IS3 and IS4), iTRAQ reagent 117; 12-month-old IS5, iTRAQ reagent 118 , and 12-month-old CS1 (an IS common sample used in both sets of experiments for comparison), iTRAQ reagent 121.

\section{Protein Digestion and Labeling with iTRAQ Reagent}

Ten micrograms of each sample were dried under vacuum prior to trypsin digestion. The general protocol for trypsin digestion and iTRAQ labeling of the peptides was similar to that recommended by Applied Biosystems Inc. (ABI, Foster City, Calif., USA) [26]. All reagents were purchased from ABI unless otherwise noted. Briefly, $20 \mu \mathrm{l}$ of dissolution buffer ( $0.5 \mathrm{M}$ triethylammoniumbicarbonate, Sigma, St. Louis, Mo., USA), pH 8.5, $1 \mu$ l of the denaturant ( $2 \%$ sodium dodecyl sulfate) and $1 \mu$ l of reducing reagent [tris-(2-carboxyethyl)phosphine] were added to each sample and incubated at $60^{\circ} \mathrm{C}$ for $1 \mathrm{~h}$. After the samples had cooled to room temperature, $1 \mu \mathrm{l}$ of a freshly prepared $84 \mathrm{~mm}$ solution of iodoacetamide was added, and the samples were incubated in the dark at room temperature for $30 \mathrm{~min}$. Sequencing grade trypsin (Promega, Madison, Wisc., USA) was reconstituted with $21 \mu \mathrm{l}$ of resuspension buffer ( $50 \mathrm{~mm}$ acetic acid), and $10 \mu \mathrm{l}$ were added to each sample. The samples were incubated at $48^{\circ} \mathrm{C}$ overnight. Each vial of iTRAQ reagent was allowed to equilibrate to room temperature and was reconstituted with $50 \mu \mathrm{l}$ of isopropanol. The contents of one iTRAQ reagent vial were added to one sample and incubated for $2 \mathrm{~h}$. After the incubation, $100 \mu \mathrm{l}$ of Milli- $Q$ water were added to each sample to quench the iTRAQ reaction, and the samples were incubated at room temperature for 30 min. All iTRAQ reagent-labeled samples were combined and dried.
Strong Cation Exchange Chromatographic Fractionation

The pooled iTRAQ-labeled peptide sample was desalted and resuspended in $500 \mu \mathrm{l}$ of cation exchange buffer $(10 \mathrm{~mm}$ potassium phosphate in $25 \%$ acetonitrile at $\mathrm{pH} 2.5-3.0$ ) prior to strong cation exchange (SCX) chromatographic fractionation and liquid chromatography (LC)-dual mass spectrometry (MS/MS) analysis using a Sep Pak ${ }^{\circledR}$ C18 Pakpeptide concentration and desalting trap (Michrom Bioresources, Auburn, Calif., USA). SCX separations were performed on a passivated Waters 600E HPLC system, using a $4.6 \times 250 \mathrm{~mm}$ PolySULFOETHYL aspartamide column (PolyLC, Columbia, Md., USA) at a flow rate of $1 \mathrm{ml} / \mathrm{min}$. Buffer A contained $10 \mathrm{mM}$ ammonium formate, $\mathrm{pH}$ 2.7, in 20\% acetonitrile $/ 80 \%$ water. Buffer B contained $666 \mathrm{mM}$ ammonium formate, pH 2.7 , in $20 \%$ acetonitrile/ $80 \%$ water.

The gradient was buffer A at 100\% (0-22 min following sample injection), $0 \rightarrow 40 \%$ buffer B (16-48 min), $40 \rightarrow 100 \%$ buffer $\mathrm{B}(48-49 \mathrm{~min})$, then isocratic $100 \%$ buffer B (49-56 min), which was switched back to $100 \%$ buffer $\mathrm{A}$ at $56 \mathrm{~min}$ to re-equilibrate for the next injection. The first $26 \mathrm{ml}$ of eluent (containing all flow-through fractions) was combined into 1 fraction, and then 14 additional 2-ml fractions were collected. All 15 of these SCX fractions were dried down completely to reduce volume and to remove the volatile ammonium formate salts, then resuspended in $9 \mu \mathrm{l}$ of $2 \%(\mathrm{v} / \mathrm{v})$ acetonitrile and $0.1 \%(\mathrm{v} / \mathrm{v})$ trifluoroacetic acid and filtered prior to reverse phase C18 nanoflow-LC separation. For 2nd-dimension separation by reverse phase nanoflow LC, each SCX fraction was autoinjected onto a Chromolith CapRod column $(150 \times 0.1 \mathrm{~mm}$, Merck) using a 5 - $\mu$ l injector loop on a Tempo LC Matrix-Assisted Laser Desorption/Ionization (MALDI) Spotting system (ABI-MDS/Sciex). Buffer C was $2 \%$ acetonitrile and $0.1 \%$ trifluoroacetic acid, and buffer D was $98 \%$ acetonitrile and $0.1 \%$ trifluoroacetic acid. The elution gradient was $95 \%$ buffer $\mathrm{C} / 5 \%$ buffer $\mathrm{D}(2 \mu \mathrm{l} / \mathrm{min}$ flow rate from 0 to $3 \mathrm{~min}$, then $2.5 \mu \mathrm{l} / \mathrm{min}$ from 3 to $8.1 \mathrm{~min}$ ), $5 \rightarrow 38 \%$ buffer $\mathrm{D}$ (8.1-40 $\mathrm{min}$ ), $38 \rightarrow 80 \%$ buffer D (41-44 $\mathrm{min}$ ) and $80 \rightarrow 5 \%$ buffer D (44-49 min; initial conditions). The flow rate was $2.5 \mu \mathrm{l} /$ min during the gradient, and an equal flow of MALDI matrix solution was added post-column $(7 \mathrm{mg} / \mathrm{ml}$ recrystallized $\alpha$-cyano-hydroxycinnamic acid, $2 \mathrm{mg} / \mathrm{ml}$ ammonium phosphate, $0.1 \%$ trifluoroacetic acid, $80 \%$ acetonitrile). The combined eluent was automatically spotted onto a stainless steel MALDI target plate every $6 \mathrm{~s}(0.6 \mu \mathrm{l}$ per spot), for a total of 370 spots per original SCX fraction.

\section{Mass Spectrometric Analysis}

After sample spot drying above, 13 calibrant spots (ABI 4700 Mix) were added manually to each plate. MALDI target plates (15 per experiment) were analyzed in a data-dependent manner on an ABI 5800 and 800 MALDI time of flight (TOF)-TOFs. As each plate was entered into the instrument, a plate calibration/ MS default calibration update was performed, and then the MS/ MS default calibration was updated. MS spectra were then acquired from each sample spot using the updated default calibration, with 500 laser shots per spot and a laser intensity of 3,200. A plate-wide interpretation was then automatically performed, choosing the highest peak of each observed mass-to-charge $(\mathrm{m} / \mathrm{z})$ value for subsequent MS/MS analysis. Up to 2,500 laser shots at a laser power of 4,200 were accumulated for each MS/MS spectrum. 
Table 1. Proteins identified in experiment 1 at critical false discovery rates

\begin{tabular}{llll}
\hline \multirow{2}{*}{ Critical FDR } & \multicolumn{3}{l}{ Number of proteins detected } \\
\cline { 2 - 4 } & local FDR & global FDR & global FDR from fit \\
\hline $1.0 \%$ & 50 & 33 & 58 \\
$5.0 \%$ & 55 & 67 & 65 \\
$10.0 \%$ & 58 & 70 & 70 \\
\hline
\end{tabular}

This table demonstrates the stringency of the $5 \%$ local false discovery rate (FDR) as compared to the $1 \%$ global FDR in experiment 1 .

\section{Data Analysis}

The software used for data acquisition was ABSciex TOF/TOF Series Explorer ${ }^{\mathrm{TM}}$. The software used for protein identification and quantitation was Protein Pilot ${ }^{\mathrm{TM}} 4.0$ software (Software Revision Number 148085, Applied Biosystems) with the integrated Paragon $^{\mathrm{TM}}$ search algorithm 4.0.0.0 (Revision Number 148083, Applied Biosystems). The iTRAQ fragment tolerance was set to $0.2 \mathrm{Da}$. The data analysis parameters were set as follows: sample type, iTRAQ (peptide labeled); Cys alkylation, iodoacetamide; digestion, trypsin; instrument, 5800; species: $M$. mulatta; ID focus: biological modifications and amino acid substitutions; database search, NCBInr rhesus monkey of 20101117 sequences, plus 156 common lab contaminants; effort, thorough; maximum missed cleavages, 2; false discovery rate analysis, yes; user-modified parameter files, no; bias correction, auto, and background correction, yes. Identified proteins were grouped by the software to minimize redundancy. All peptides used for the calculation of protein ratios were unique to the given protein or proteins within the group, and peptides that were common to other isoforms or proteins of the same family were ignored. The protein confidence threshold cutoff is 1.3 (unused ProtScore) with at least one peptide with $95 \%$ confidence. Average iTRAQ ratios were obtained from at least 3 experiments using like samples (either IDA or IS and at either 6 or 12 months). In addition, the only protein IDs accepted had a 'local false discovery rate' estimation of no higher than 5\%, as calculated from the slope of the accumulated decoy database hits by the Proteomics System Performance Evaluation Pipeline [27]. We choose to utilize the $5 \%$ local false discovery rate versus the $1 \%$ global false discovery rate because that value was shown to provide more stringent results (tables 1,2).

\section{Statistical Analysis}

Hematological differences between IS and IDA infants were confirmed with analyses of variance, considering iron status as a between factor and infant age as a repeated measure. Protein profiles were compared between IS and IDA infants utilizing the Mann-Whitney $\mathrm{U}$ test with $\alpha$ set at $\mathrm{p}<0.05$.
Table 2. Proteins identified in experiment 2 at critical false discovery rates

\begin{tabular}{llll}
\hline \multirow{2}{*}{ Critical FDR } & \multicolumn{3}{l}{ Number of proteins detected } \\
\cline { 2 - 4 } & local FDR & global FDR & global FDR from fit \\
\hline $1.0 \%$ & 86 & 86 & 88 \\
$5.0 \%$ & 87 & 91 & 92 \\
$10.0 \%$ & 87 & 102 & 99 \\
\hline
\end{tabular}

This table demonstrates the stringency of the $5 \%$ local false discovery rate (FDR) as compared to the $1 \%$ global FDR in experiment 2 .

\section{Results}

\section{Hematology}

Based on the hematology tests, 8 infant monkeys were classified as anemic (IDA) at weaning age and 5 were IS when the first CSF specimens were collected (table 3). By 1 year of age, the hematological parameters of the formerly IDA infants had returned to the normal range and were no longer significantly different from the yearlings that had been IS across the whole first year of life (fig. 1).

\section{Effect of Age on the CSF Protein Profile of the IDA Monkeys (Experiment 1)}

A database search of MS/MS spectra identified 46 proteins at the $95 \%$ confidence level, and the complete list is provided in appendix $\mathrm{A}$ in the online supplementary materials (for all online supplementary material, see www. karger.com/doi/10.1159/000341919). The total protein scores are presented in order from highest to lowest. Among the proteins detected, 21 proteins were identified with one unique peptide with a minimum peptide confidence of $95 \%$. The false positive peptide rate calculated from the reversed database search results was between $0.01>\mathrm{p}>0.001$.

For protein quantification, peak areas for iTRAQ tag peaks (113-121 m/z) were determined, and after normalization of sample quantities using median ratios (Paragon algorithm search, ProteinPilot 3.0 software), differential expression between the CSF samples of IDA infants at weaning age $(113,114,115$ and $116 \mathrm{~m} / \mathrm{z})$ and an internal standard $(121 \mathrm{~m} / \mathrm{z})$ or subsequently at 1 year of age $(117$, 118 and $119 \mathrm{~m} / \mathrm{z})$ and an internal standard $(121 \mathrm{~m} / \mathrm{z})$ were determined. Differentially expressed proteins in the CSF between the two age points were identified using nonparametric statistical tests, and 2 proteins were identified 
Table 3. Mean \pm SE and individual hematological values for IDA and IS infant monkeys from which CSF was collected for the iTRAQ analyses

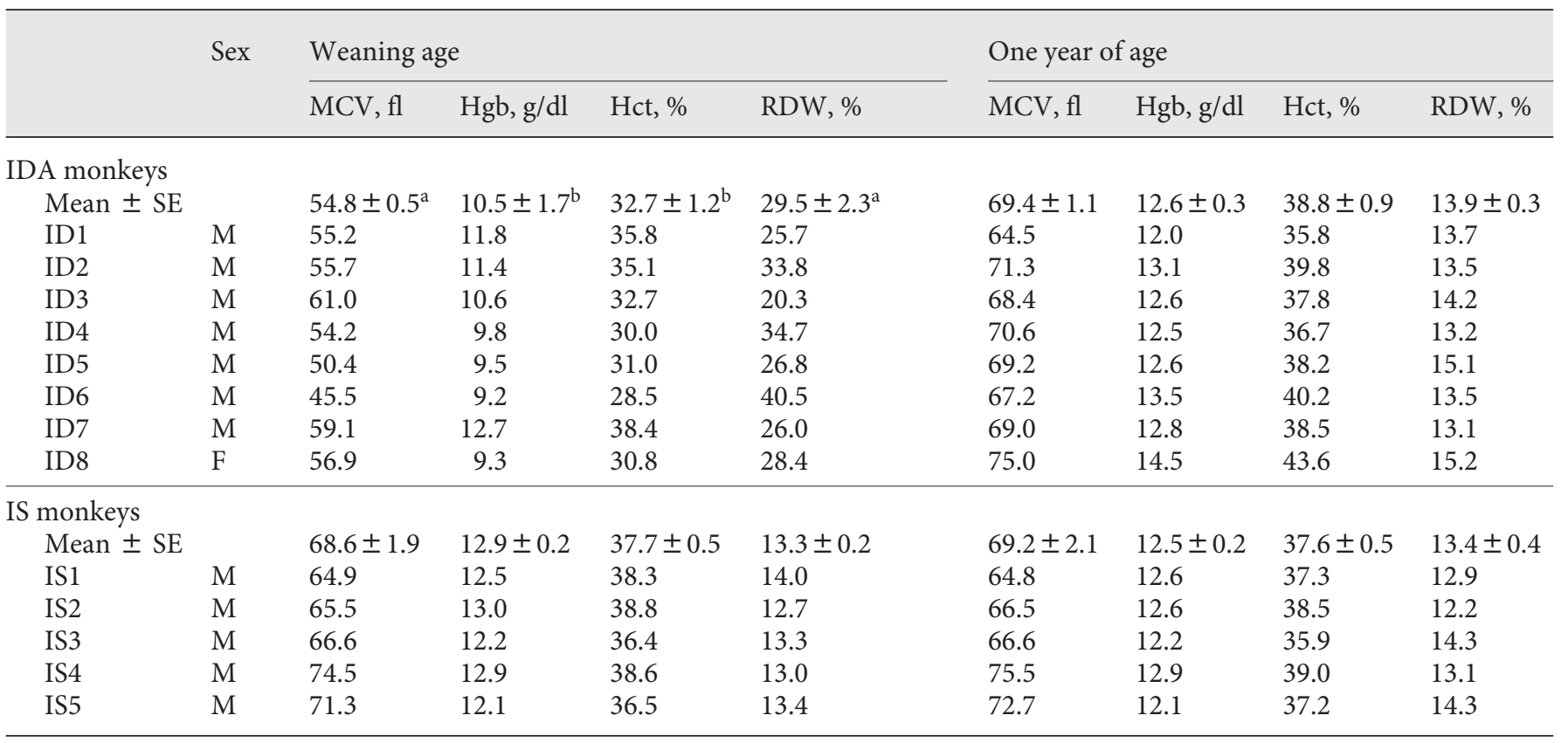

MCV = Mean corpuscular volume; Hgb = hemoglobin; Hct = hematocrit; RDW = red blood cell distribution width.

a Significantly lower in anemic infants at 6-7 months of age, $\mathrm{p}<0.001$; $^{\mathrm{b}}$ significantly lower in anemic infants at 6-7 months of age, $\mathrm{p}<0.02$.

Fig. 1. Hematological parameters in infant monkeys. This figure summarizes the iron-related hematological parameters of the rhesus monkeys assessed in this study. The mean corpuscular volume (MCV) and hemoglobin (Hgb) values clearly demonstrate the anemic status of some infants at weaning age, which then resolved by 1 year of age. Mean \pm SE values for the individual data presented in table 1 are shown.

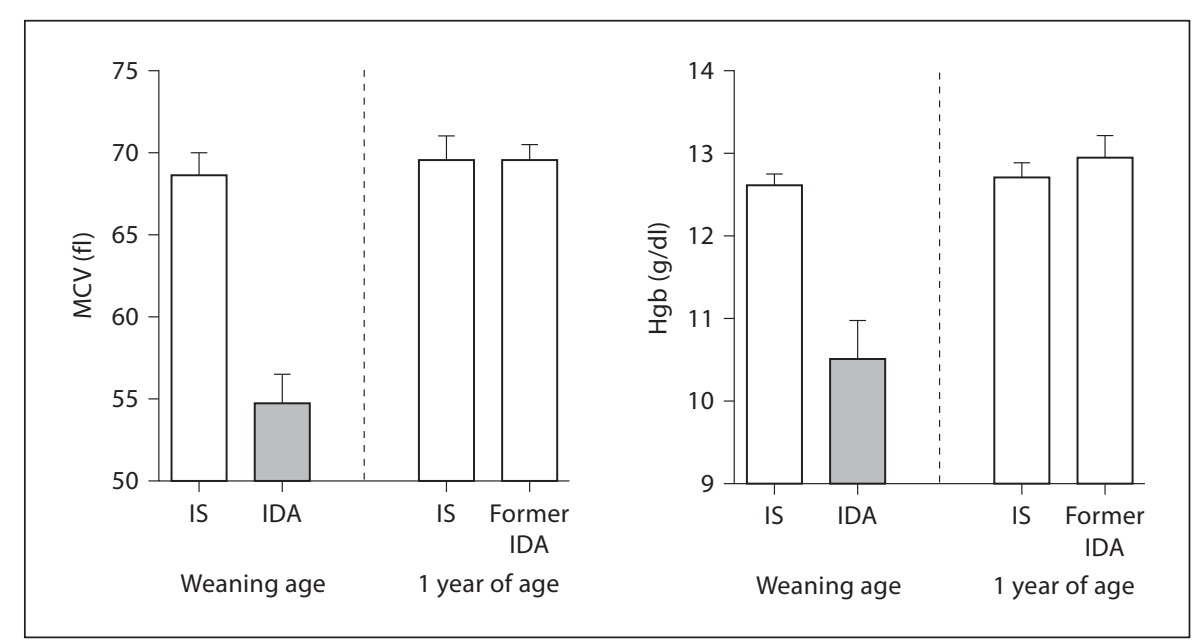

that met significance ( $\mathrm{p} \leq 0.05)$. As shown in table 4 , both proteins (apolipoprotein $\mathrm{E}$ and proactivator polypeptide-like isoform) identified using iTRAQ were higher in the CSF samples from anemic infants at the weaning age.

\section{Effect of Age on the CSF Protein Profile in the IS} Monkeys (Experiment 2)

A database search of MS/MS spectra identified 74 proteins at the $95 \%$ confidence level, and the ordered list of total protein scores from high to low is provided in 
Table 4. Effect of age on protein expression in the CSF of IDA and IS infant monkeys

\begin{tabular}{lll}
\hline Protein & $\begin{array}{l}\text { Mean fold } \\
\text { change } \\
\text { from 6 to } \\
12 \text { months }\end{array}$ & $\begin{array}{l}\mathrm{p} \\
\text { value }\end{array}$ \\
& & \\
\hline IDA monkeys & 2.35 & 0.029 \\
Apolipoprotein E & 7.48 & 0.029 \\
Proactivator polypeptide-like isoform 7 & & \\
IS monkeys & 0.73 & 0.050 \\
Transferrin & 0.62 & 0.050 \\
Clusterin & 0.88 & 0.050 \\
Amyloid $\beta$ A4 precursor-like protein 1 & & \\
$\quad$ isoform 1 & 0.52 & 0.050 \\
Pro-SAAS-like protein & & \\
\hline
\end{tabular}

SAAS $=$ Proprotein convertase subtilisin/kexin type 1 inhibitor.

appendix B (online suppl. materials). Among the proteins detected, 36 proteins were identified with one unique peptide with a minimum peptide confidence of $95 \%$. The false positive peptide rate calculated from the reversed database search results was between $0.01>p>$ 0.001 .

For protein quantification, peak areas for iTRAQ tag peaks (113-118 and $121 \mathrm{~m} / \mathrm{z})$ were determined, and after normalization of sample quantities using median ratios (Paragon algorithm search, ProteinPilot 3.0 software), differential expression between CSF from the IS infants at 6 months $(113,114$ and $115 \mathrm{~m} / \mathrm{z})$ and an internal standard $(121 \mathrm{~m} / \mathrm{z})$ or between the CSF from the IS yearlings $(116,117$ and $118 \mathrm{~m} / \mathrm{z})$ and an internal standard $(121 \mathrm{~m} / \mathrm{z})$ were determined. Differentially expressed proteins between 6-7 months and 1 year of age were identified, and 4 proteins met statistical significance $(\mathrm{p} \leq 0.05)$. As shown in table 4 , all of the identified proteins (transferrin, clusterin, amyloid $\beta$ A4 precursor-like protein 1 and pro-SAAS-like protein) were lower at weaning age than at 1 year of age.

\section{Effect of Iron Status on CSF Protein Profiles at}

Weaning Age

In order to examine the effect of iron status on the CSF profile at 6-7 months of age, the outputs from the two iTRAQ experiments were reduced to a table of reporter ion intensities relative to the intensity of the internal standard $(121 \mathrm{~m} / \mathrm{z})$ for each peptide across the multiplexed samples constituting each run. We identified 11 proteins
Table 5. Effect of iron status on protein expression in the CSF of infant monkeys at weaning age

\begin{tabular}{lll}
\hline Protein & $\begin{array}{l}\text { Mean fold } \\
\text { difference } \\
\text { between } \\
\text { IDA and IS }\end{array}$ & $\begin{array}{l}\mathrm{p} \\
\text { value }\end{array}$ \\
& & \\
\hline Prostaglandin-H2 D-isomerase & 0.25 & 0.029 \\
AAT isoform 4 & 0.33 & 0.037 \\
Mamu IgG-rh1 heavy chain & 0.53 & 0.029 \\
Hemopexin-like & 0.85 & 0.029 \\
Gelsolin isoform 18 & 0.57 & 0.037 \\
TLR8 & 0.45 & 0.029 \\
Amyloid $\beta$ A4 protein-like & 1.80 & 0.029 \\
Complement factor H-like isoform 3 & 1.17 & 0.029 \\
Chromobox protein homolog 6 isoform 1 & 1.78 & 0.029 \\
Hypothetical protein LOC 706413 & 1.38 & 0.029 \\
Fibronectin & 4.14 & 0.029 \\
\hline
\end{tabular}

that were common to both IS and IDA samples that met statistical criteria for significance $(\mathrm{p} \leq 0.05)$. As shown in table 5, 6 proteins were lower in the CSF of the IDA infants [prostaglandin-H2 D-isomerase, $\alpha$-1-antitrypsin (AAT) isoform 4, Mamu IgG-rh1 heavy chain, hemopexin, gelsolin and toll-like receptor 8 (TLR8)]. Five proteins (amyloid $\beta$ A4 protein, complement factor $\mathrm{H}$, chromobox protein homolog 6, hypothetical protein LOC 706413 and fibronectin) were found to be at higher concentrations in the CSF of the IDA infants when compared to CSF samples of the IS infants.

\section{Effect of Iron Status on CSF Protein Profiles in}

Monkeys at One Year of Age

Similar comparisons were conducted on the outputs from iTRAQ experiments run on CSF from yearling monkeys. The data were reduced to a table of reporter ion intensities relative to the intensity of the internal standard $(121 \mathrm{~m} / \mathrm{z})$ for each peptide across the multiplexed samples constituting each run. We identified 12 proteins common to the CSF from IS and IDA monkeys that met statistical criteria for significance ( $\mathrm{p} \leq 0.05)$. As shown in table 6,10 proteins were lower in the CSF of the yearling monkeys that had previously been iron-deficient (apolipoprotein E, prostaglandin-H2 D-isomerase, AAT isoform 4, apolipoprotein A-I, clusterin, TLR8, fibulin-1, protein kinase C-binding protein NELL2, serpin peptidase inhibitor, clade A and proactivator polypeptide-like isoform 7). At the same time, when compared to the iTRAQ data for monkeys that had been continuously IS, 
Table 6. Effect of prior iron status at weaning age on the protein expression in the CSF of yearling monkeys

\begin{tabular}{lll}
\hline Protein & $\begin{array}{l}\text { Mean fold } \\
\text { difference } \\
\text { between } \\
\text { IDA and IS }\end{array}$ & $\begin{array}{l}\mathrm{p} \\
\text { value }\end{array}$ \\
& 0.41 & 0.050 \\
\hline Apolipoprotein E & 0.34 & 0.050 \\
Prostaglandin-H2 D-isomerase & 0.42 & 0.050 \\
AAT isoform 4 & 0.38 & 0.050 \\
Apolipoprotein A-I isoform 3 & 0.71 & 0.050 \\
Clusterin & 0.54 & 0.050 \\
TLR8 & 0.49 & 0.050 \\
Fibulin-1 isoform 2 & 1.60 & 0.038 \\
Amyloid $\beta$ A4 protein-like, partial & & \\
Protein kinase C-binding protein NELL2 & 0.66 & 0.050 \\
$\quad$ isoform 2 & 0.66 & 0.038 \\
Serpin peptidase inhibitor, clade A, & & \\
$\quad$ member 3 & 0.15 & 0.050 \\
Proactivator polypeptide-like isoform 7 & 2.74 & 0.050 \\
Fibronectin & &
\end{tabular}

there were 2 proteins that were elevated in the CSF of the former IDA monkeys (amyloid $\beta$ A4 protein and fibronectin).

\section{Discussion}

Our study shows that CSF can be utilized to demonstrate the significant effect that iron status, as well as age, has on critical biochemical pathways in the CNS. The iTRAQ methodology was chosen because it not only identifies proteins of interest but also permits accurate quantification, allowing for key comparisons in a systematic manner. A previous study of IDA in infant monkeys using two-dimensional analyses [19] revealed that a distinct CSF protein profile persisted for over 4 months after the period of anemia and was still evident in infants that received 2 months of ferrous sulfate treatment. The current results confirm and extend those findings. Because of the sensitivity of the iTRAQ techniques, we have now identified 5 additional proteins that remain persistently altered in the CSF. These proteins are prostaglandin- $\mathrm{H} 2$ $\mathrm{D}$-isomerase, AAT, TLR8, amyloid $\beta$ A4 precursor protein and fibronectin. Prostaglandin-H2 D-isomerase, AAT and TLR8 were decreased in the CSF both during and subsequent to the anemic period, whereas amyloid $\beta$ A4 precursor protein and fibronectin remained increased through 1 year of age, even though the monkeys were consuming fortified solid foods and now evinced normal hematological values (fig. 2). A number of these proteins are likely to be associated with the behavioral deficits that have been observed in iron-deficient children [8, 28, 29].

Although we are unaware of other studies in the literature that have utilized iTRAQ methodology in either infant monkeys or humans, we know that iTRAQ studies using adult human CSF have, in fact, identified many more proteins than our study [30-32]. One reasonable explanation for the more limited number of identified proteins compared to adult human CSF studies could be the lower total protein concentration in infant monkey CSF. Total protein concentrations in normal human adults range from 300 to $700 \mathrm{ng} / \mu \mathrm{l}$ [33]. Protein concentrations recovered from the CSF of infant monkeys were considerably lower (approximately 100-200 ng/ $\mu \mathrm{l}$ ). These differences in protein concentration could reflect adult versus infants or species differences. Our data compare favorably to the only other published results for protein concentrations in monkey CSF [34], where CSF from adult monkeys with HIV-1-associated neurological disorders was examined and a similar protein concentration (146 proteins) was identified from $10 \mu \mathrm{g}$ of total protein using MS analyses.

This study is consistent with both rat and mouse models of early iron deficiency that documented persistent neurochemical and behavioral alterations even after the iron deficiency is corrected. In the mouse model, chronic marginal iron intake during early development has been shown to disrupt brain iron levels, motor and cognitive performance, dopamine metabolism and myelin composition [35-37]. Similarly, in the rat model of early iron deficiency, deficits in monoamine metabolism, myelin synthesis and energy metabolism and alterations in the neurochemical profiles have been demonstrated [17, 3841]. In the rat model of early iron deficiency, the persistence of deficits in the monoamine pathways is dependent on the timing of the iron deficiency [42]. In nonhuman primates, the timing of the iron deficiency insult has also been shown to be critical to the development of certain behaviors. Prenatal iron deficiency led to increased impulsive behavior, whereas postnatal iron deficiency resulted in more passive behavior [43]. Monkeys that experience IDA during development also perform more poorly on a cognition test (reversal learning) even after the systemic iron deficiency has been corrected [44], consistent with the current report of prolonged alterations in the CSF proteome.

There were 5 proteins that were altered in the CSF despite the replenishment of iron. One protein identified by 


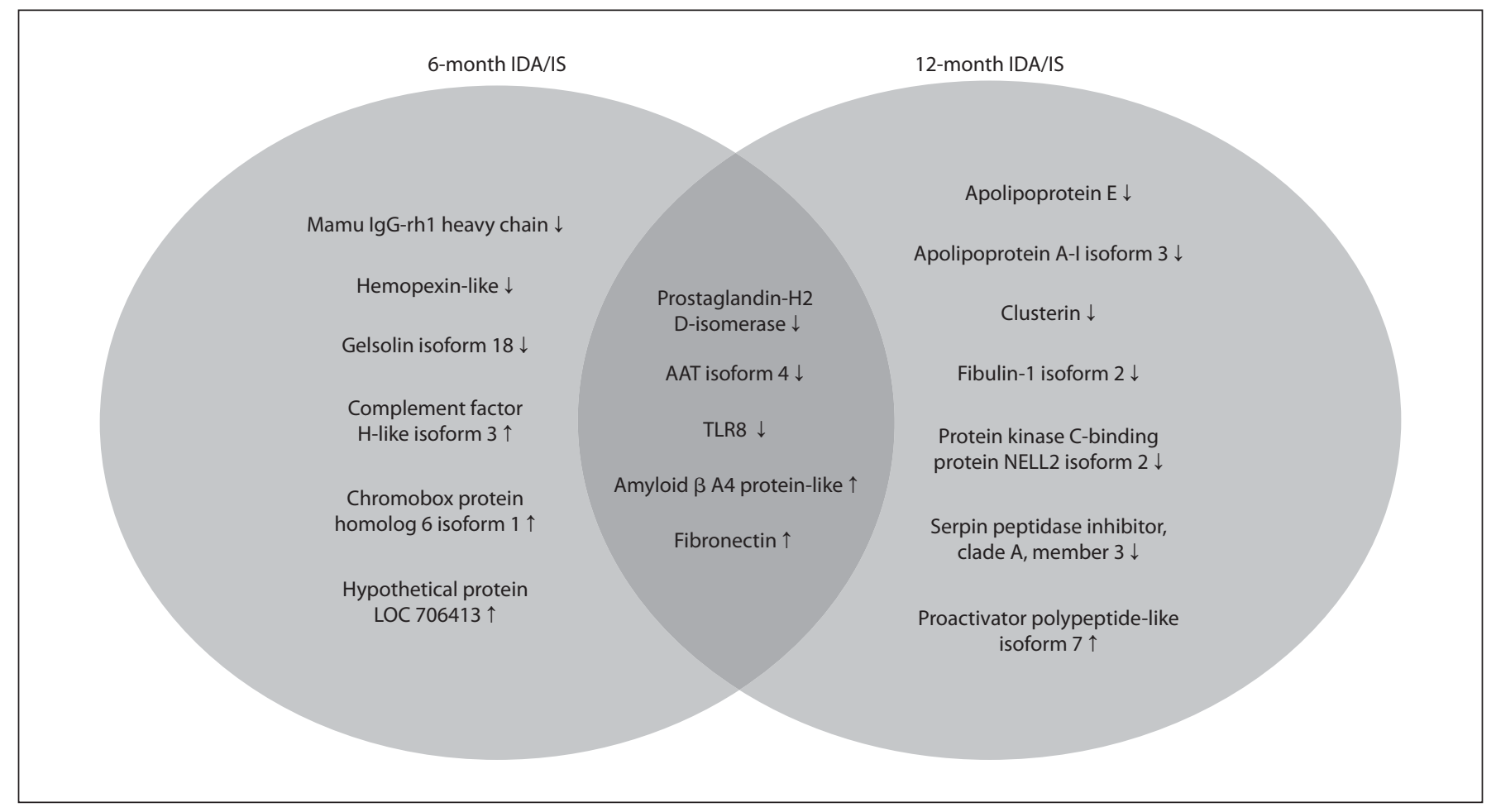

Fig. 2. Venn diagram of CSF protein alterations in IDA infants. This figure summarizes the significant protein changes identified in the CSF of anemic infant monkeys. The left oval identifies protein differences at weaning age (6-7 months) during the period of anemia; the right oval portrays those proteins altered at 1 year of age. The overlapping region highlights CSF proteins that were altered at 6-7 months and remained abnormal at 1 year despite correction of the underlying iron deficiency. Arrows reflect the direction of change. our iTRAQ study that was also altered in our previous study [19] was prostaglandin-H2 D-isomerase, which is also referred to as prostaglandin D2 (PGD2) synthase (PGDS) and functions to catalyze the conversion of prostaglandin $\mathrm{H} 2$ to PGD2. PGDS is produced in the leptomeninges and choroid plexus, and the enzymatic product PGD2 is a neuromodulator as well as a trophic factor in the CNS. PGD2 has potent somnogenic effects and has been implicated in the regulation of non-rapid eye movement sleep $[45,46]$. Thus, it may be involved in and reflect the sleep disturbances and fatigue frequently experienced by anemic individuals. Sleep disruption also contributes to cognitive impairments, deficits in attention and increased emotional reactivity [47-49]. There is some evidence that attention problems comparable to attention deficit disorder are associated with iron deficiency [29]. Because PGDS levels remained decreased in the ironchallenged infant monkey, despite the correction of ironrelated deficits in the blood compartment, it suggests that further research should be conducted on the sleep/wake cycles and activity patterns in previously anemic children.

A second protein downregulated in the CSF was AAT. AAT is a protease inhibitor that belongs to the serpin superfamily and is a serum trypsin inhibitor. It protects tissues from enzymes produced by inflammatory cells, and its concentration can rise with acute inflammation. Decreased levels of AAT, similar to those found in our study of anemic infant monkeys, have been described in genetic AAT deficiency, which is caused by mutations in the AAT gene [50]. Classic AAT deficiency increases an individual's vulnerability to environmentally induced liver and lung disease [51-54]. However, two types of AAT polymorphisms are associated with a milder form of the disease, an increased age of onset and decreased symptom severity. Individuals with these genotypes have a higher prevalence of mood disorders, specifically anxiety and bipolar disorders [55]. In addition, younger carriers of these AAT polymorphisms often present with attention deficit problems or learning disabilities [56]. In ad- 
dition to its role in regulating inflammation, AAT is involved in iron homeostasis by inhibiting the interaction between transferrin and its receptor [57] as well as by binding precursor molecules for hepcidin [58], which could alter a cell's ability to retain iron. Because the CSF levels of AAT remained low despite improvements in the blood indices, it is likely that iron-related dysfunction persists within the CNS. This conclusion is supported by our other research on infant monkeys, which demonstrated that dopaminergic activity is lower and norepinephrine activity is elevated subsequent to the period of anemia [9]. In addition, CSF from anemic monkeys was found to have an enhanced chemoattraction for iron when examined in vitro with an endothelial cell model of the blood-blood barrier, which we believe is due to elevated levels of iron-poor transferrin and decreased levels of hepcidin (in preparation).

Several proteins identified as remaining altered despite improvements in peripheral iron status are involved in neuronal migration, outgrowth and signaling. One particularly important protein is TLR8. Although TLR8 was first described as playing a crucial role in pathogen recognition and innate immunity [59], it is also involved in neurite outgrowth and the regulation of neuronal apoptosis [60]. TLR8 is highly expressed during development and is present in the growth cones of cultured cortical neurons [60]. While TLR8 expression declines normally in the adult brain, it can be upregulated during certain pathologies, suggesting that it has a function in the regulation of axonal dynamics. Our iTRAQ analyses revealed a sustained decrease in TLR8 expression in spite of the resolution of the peripheral anemia. Such a persistent decrease may impact neurite outgrowth and contribute to the abnormal axonal transport that has been described in the rat and mouse models of anemia [61, 62]. MRI evaluations of children with autism, a developmental disorder involving pervasive deficits in social proficiency and communication, have indicated that many have an early period of brain overgrowth followed by abnormally slow growth in some brain regions and premature cessation of growth in others [63]. It is possible that aberrations in the regulation of neuritogenic pathways induced by early iron deficiency recreate a milder version of these abnormalities in similar socioemotional, cognitive and motor domains.

Amyloid precursor protein (APP) was increased in the CSF even after the anemia resolved. APP has been extensively studied because of its role in the biogenesis of $A \beta$ and the neuropathology of Alzheimer's disease $(\mathrm{AD})$, and more recently it has been associated with fer- roxidase activity [64] and potentially the main mechanism for iron export from neurons [65]. Our data may suggest that elevated APP in the CSF could reflect increased turnover of APP as a compensatory mechanism for neurons to retain more iron. The increased APP in CSF is also consistent with alterations in neuronal migration as it is involved in neurite outgrowth as well as synaptic structure/function and cell targeting [66]. During neuronal differentiation, higher APP levels have been reported $[67,68]$, and pronounced increases in APP levels were detected in brain homogenates, growth cones and synaptosomes during times of increased synapse formation [69]. Recently, it was reported that plasma from children with severe autism and aggressivity contains increased levels of total soluble APP [70] and soluble APP $\alpha$ [71]. This finding has led researchers to hypothesize that increased levels of APP in the CNS during development result in accelerated migration of precursor cells in the cortex and suppression of cell adhesion support, and that this dysregulation contributes to the brain overgrowth observed in autism $[63,72]$. Given the current data on APP changes in the CSF during iron deficiency and the neurological interest in CSF concentrations of $A \beta$ as a biomarker in $A D$, the contribution of brain iron status to the changes in CSF $A \beta$ may be important. There is considerable evidence for a loss of brain iron homeostasis in AD [73]. Although the amount of iron is increased in the brains of individuals with $\mathrm{AD}$, the bioavailabilty of this iron to neurons has been questioned given the amount of iron bound up in neuritic plaques [73], and it may also be retained in neurons as a result of loss of ferroxidase activity of APP [64]. Another possible connection between brain iron status and the emergence of $\mathrm{AD}$ in the older individual can also be drawn from our finding that apolipoprotein $\mathrm{E}$ was altered in the CSF during the period of frank anemia at 6-7 months of age. The combination of an apolipoprotein E4 mutation and a variant form of the HFE gene (which is also involved in iron regulation) will significantly lower the age of onset of AD [74]. The observation that iron deficiency impacts APP expression may add additional iron-related stress to neurons.

A third upregulated protein was fibronectin. Fibronectin is a high-molecular weight glycoprotein found in the extracellular matrix (ECM) which binds to membranespanning receptor proteins called integrins [75] and also binds ECM components including collagen, fibrin and heparan sulfate proteoglycans (e.g. syndecans). Its primary functions are to promote adhesion and phagocytosis $[76,77]$. In the CNS, the ECM provides directional cues 
for neuronal development [78] and is a critical mediator in the development and regeneration of the sensory nervous system [79]. Dynamic changes in ECM composition occur during maturation and help to facilitate neuronal migration in the developing brain. Therefore, the upregulation of fibronectin further suggests that neurite outgrowth in the developing brain is significantly and chronically altered by iron deficiency and provides new evidence for the essential involvement of iron in neuritogenic pathways.

\section{Conclusion}

iTRAQ analyses were conducted on the CSF of infant monkeys to identify differential protein expression as a result of early iron deficiency. Two limitations of this current study are the small number of monkeys that were evaluated and the need for further validation of the findings. Nevertheless, the expression of 5 proteins appeared to remain altered at two age points despite the consumption of fortified foods after weaning, a diet that was adequate to restore hematological indices into the normal range, and one protein (PGDS) was also altered in a previous report in a similar model using a different technical approach. These findings thus confirm reports of a preferential prioritization of iron to peripheral tissues, including red blood cells, liver and muscle, before the restoration of the low iron reserves in the CNS [80]. The majority of the identified proteins with altered concentration in the CSF are involved in neuritogenic pathways (i.e. neurite outgrowth, migration or synapse formation), and one protein, APP, has a direct role in iron retention by neurons. Based on these changes, it is reasonable to conclude that iron deficiency will undermine brain growth and result in aberrant neuronal migration and connections. Taken together with gene expression data from rodent models of iron deficiency, we conclude that iron deficiency causes significant alterations in neuroconnectivity in the maturing brain, and some persist even after resolution of the systemic iron deficiency. The compromised brain infrastructure could account for the observations of behavioral deficits in children during and after the period of anemia. Moreover, these findings confirm the long-lasting effects of iron deficiency that have been detected upon histological and neurochemical examination of the brain, which may also establish a predisposition for adult neurodegenerative disorders later in the life span. The data indicate that the prevailing strategies deemed adequate to rescue iron deficiency on the basis of correcting hematologic parameters are likely inadequate for addressing the full impact of iron deficiency on the brain.

\section{Acknowledgements}

This work was supported by grants from the National Institutes of Health (P01 HD39386, R01 HD057064) and Gates Foundation (OPP10462903). The content is solely the responsibility of the authors and does not necessarily represent the official views of the National Institutes of Health. The Penn State Mass Spectrometry Core Facility services and instruments used in this project were funded, in part, under a grant with the Pennsylvania Department of Health using Tobacco Settlement Funds. The Department specifically disclaims responsibility for any analyses, interpretations or conclusions. The authors thank Anne Stanley from the Penn State Mass Spectrometry Core for her technical assistance and Dr. Bruce Stanley for helpful discussions.

\section{References}

1 Stoltzfus RJ, Dreyfuss ML, Chwaya HM, Albonico M: Hookworm control as a strategy to prevent iron deficiency. Nutr Rev 1997;55: 223-232.

-2 Looker AC, Dallman PR, Carroll MD, Gunter EW, Johnson CL: Prevalence of iron deficiency in the United States. JAMA 1997;277: 973-976.

3 McLoyd VC: Socioeconomic disadvantage and child development. Am Psychol 1998;53: 185-204.

-4 Cusick SE, Mei Z, Freedman DS, Looker AC, Ogden CL, Gunter E, Cogswell ME: Unexplained decline in the prevalence of anemia among US children and women between 1988-1994 and 1999-2002. Am J Clin Nutr 2008;88:1611-1617.
5 Lozoff B: Iron deficiency and child development. Food Nutr Bull 2007;28:S560-S571.

6 Lozoff B, Wolf AW, Jimenez E: Iron-deficiency anemia and infant development: effects of extended oral iron therapy. J Pediatr 1996; 129:382-389

7 Lozoff B, Georgieff MK: Iron deficiency and brain development. Semin Pediatr Neurol 2006;13:158-165.

8 Lozoff B, Jimenez E, Hagen J, Mollen E, Wolf AW: Poorer behavioral and developmental outcome more than 10 years after treatment for iron deficiency in infancy. Pediatrics 2000;105:E51.

-9 Coe CL, Lubach GR, Bianco L, Beard JL: A history of iron deficiency anemia during infancy alters brain monoamine activity later in juvenile monkeys. Dev Psychobiol 2009; 51:301-309.

10 Jorgenson LA, Wobken JD, Georgieff MK: Perinatal iron deficiency alters apical dendritic growth in hippocampal CA1 pyramidal neurons. Dev Neurosci 2003;25:412-420.

11 Ward KL, Tkac I, Jing Y, Felt B, Beard J, Connor J, Schallert T, Georgieff MK, Rao R: Gestational and lactational iron deficiency alters the developing striatal metabolome and associated behaviors in young rats. J Nutr 2007; 137:1043-1049.

12 Rao R, Tkac I, Townsend EL, Gruetter R, Georgieff MK: Perinatal iron deficiency alters the neurochemical profile of the developing rat hippocampus. J Nutr 2003;133: 3215-3221. 
13 Beard J: Iron deficiency alters brain development and functioning. J Nutr 2003;133: 1468S-1472S

14 Ortiz E, Pasquini JM, Thompson K, Felt B, Butkus G, Beard J, Connor JR: Effect of manipulation of iron storage, transport, or availability on myelin composition and brain iron content in three different animal models. J Neurosci Res 2004;77:681-689.

15 Borel MJ, Beard JL, Farrell PA: Hepatic glucose production and insulin sensitivity and responsiveness in iron-deficient anemic rats. Am J Physiol 1993;264:E380-E390.

-16 de Deungria M, Rao R, Wobken JD, Luciana M, Nelson CA, Georgieff MK: Perinatal iron deficiency decreases cytochrome c oxidase (CytOx) activity in selected regions of neonatal rat brain. Pediatr Res 2000;48:169-176

-17 Carlson ES, Fretham SJ, Unger E, O'Connor M, Petryk A, Schallert T, Rao R, Tkac I, Georgieff MK: Hippocampus specific iron deficiency alters competition and cooperation between developing memory systems. J Neurodev Disord 2010;2:133-143.

-18 Tkac I, Rao R, Georgieff MK, Gruetter R: Developmental and regional changes in the neurochemical profile of the rat brain determined by in vivo $1 \mathrm{H}$ NMR spectroscopy. Magn Reson Med 2003;50:24-32.

19 Geguchadze RN, Coe CL, Lubach GR, Clardy TW, Beard JL, Connor JR: CSF proteomic analysis reveals persistent iron deficiency-induced alterations in non-human primate infants. J Neurochem 2008;105:127136.

20 Thompson EJ: Cerebrospinal Fluid: CSF Proteins and Their Relevance in Research, Diagnostics and treatment. London, Elsevier Academic Press, 2004.

-21 Yuan X, Russell T, Wood G, Desiderio DM: Analysis of the human lumbar cerebrospinal fluid proteome. Electrophoresis 2002;23: 1185-1196.

22 Reyes TM, Coe CL: The proinflammatory cytokine network: interactions in the CNS and blood of rhesus monkeys. Am J Physiol 1998;274:R139-R144.

23 Lubach GR, Coe CL: Preconception maternal iron status is a risk factor for iron deficiency in infant rhesus monkeys (Macaca mulatta). J Nutr 2006;136:2345-2349.

-24 Bicknese EJ, George JW, Hird DW, PaulMurphy J, Anderson JA, Roberts JR: Prevalence and risk factors for iron deficiency anemia in weanling rhesus macaques. Lab Anim Sci 1993;43:434-438.

25 Kriete MF, Champoux M, Suomi SJ: Development of iron deficiency anemia in infant rhesus macaques. Lab Anim Sci 1995;45:1521.

-26 Ogata Y, Charlesworth MC, Higgins L, Keegan BM, Vernino S, Muddiman DC: Differential protein expression in male and female human lumbar cerebrospinal fluid using iTRAQ reagents after abundant protein depletion. Proteomics 2007;7:3726-3734.
27 Tang WH, Shilov IV, Seymour SL: Nonlinear fitting method for determining local false discovery rates from decoy database searches. J Proteome Res 2008;7:3661-3667.

28 Corapci F, Calatroni A, Kaciroti N, Jimenez E, Lozoff B: Longitudinal evaluation of externalizing and internalizing behavior problems following iron deficiency in infancy. J Pediatr Psychol 2010;35:296-305.

29 Lukowski AF, Koss M, Burden MJ, Jonides J, Nelson CA, Kaciroti N, Jimenez E, Lozoff B: Iron deficiency in infancy and neurocognitive functioning at 19 years: evidence of longterm deficits in executive function and recognition memory. Nutr Neurosci 2010;13: 54-70.

30 Wenner BR, Lovell MA, Lynn BC: Proteomic analysis of human ventricular cerebrospinal fluid from neurologically normal, elderly subjects using two-dimensional LC-MS/MS J Proteome Res 2004;3:97-103.

31 Zougman A, Pilch B, Podtelejnikov A, Kiehntopf M, Schnabel C, Kumar C, Mann $\mathrm{M}$ : Integrated analysis of the cerebrospinal fluid peptidome and proteome. J Proteome Res 2008;7:386-399.

32 Schutzer SE, Liu T, Natelson BH, Angel TE, Schepmoes AA, Purvine SO, Hixson KK, Lipton MS, Camp DG, Coyle PK, Smith RD, Bergquist J: Establishing the proteome of normal human cerebrospinal fluid. PLoS One 2010;5:e10980.

-33 Rozek W, Ricardo-Dukelow M, Holloway S, Gendelman HE, Wojna V, Melendez LM, Ciborowski P: Cerebrospinal fluid proteomic profiling of HIV-1-infected patients with cognitive impairment. J Proteome Res 2007; 6:4189-4199.

-34 Wikoff WR, Pendyala G, Siuzdak G, Fox HS: Metabolomic analysis of the cerebrospinal fluid reveals changes in phospholipase expression in the CNS of SIV-infected macaques. J Clin Invest 2008;118:2661-2669.

35 Kwik-Uribe CL, Golubt MS, Keen CL: Behavioral consequences of marginal iron deficiency during development in a murine model. Neurotoxicol Teratol 1999;21:661672.

36 Kwik-Uribe CL, Gietzen D, German JB, Golub MS, Keen CL: Chronic marginal iron intakes during early development in mice result in persistent changes in dopamine metabolism and myelin composition. J Nutr 2000;130:2821-2830.

-37 Kwik-Uribe CL, Golub MS, Keen CL: Chronic marginal iron intakes during early development in mice alter brain iron concentrations and behavior despite postnatal iron supplementation. J Nutr 2000;130:20402048.

8 Youdim MB, Green AR: Iron deficiency and neurotransmitter synthesis and function. Proc Nutr Soc 1978;37:173-179.

39 Dallman PR: Biochemical basis for the manifestations of iron deficiency. Annu Rev Nutr 1986;6:13-40.
40 Beard J, Erikson KM, Jones BC: Neonatal iron deficiency results in irreversible changes in dopamine function in rats. J Nutr 2003; 133:1174-1179.

41 Rao R, Tkac I, Schmidt AT, Georgieff MK: Fetal and neonatal iron deficiency causes volume loss and alters the neurochemical profile of the adult rat hippocampus. Nutr Neurosci 2011;14:59-65.

42 Felt BT, Beard JL, Schallert T, Shao J, Aldridge JW, Connor JR, Georgieff MK, Lozoff B: Persistent neurochemical and behavioral abnormalities in adulthood despite early iron supplementation for perinatal iron deficiency anemia in rats. Behav Brain Res 2006; 171:261-270.

43 Golub MS: Recent studies of iron deficiency during brain development in nonhuman primates. Biofactors 2010;36:111-116.

44 Lubach GR, Coe CL: Selective impairment of cognitive performance in the young monkey following recovery from iron deficiency. J Dev Behav Pediatr 2008;29:11-17.

45 Urade Y, Hayaishi O: Prostaglandin D synthase: structure and function. Vitam Horm 2000;58:89-120.

46 Urade Y, Hayaishi O: Prostaglandin D(2) and sleep/wake regulation. Sleep Med Rev 2011;15:411-418.

47 Durmer JS, Dinges DF: Neurocognitive consequences of sleep deprivation. Semin Neurol 2005;25:117-129.

48 Jones K, Harrison Y: Frontal lobe function, sleep loss and fragmented sleep. Sleep Med Rev 2001;5:463-475.

49 Walker MP: Cognitive consequences of sleep and sleep loss. Sleep Med 2008;9(suppl 1): S29-S34.

50 Janciauskiene SM, Bals R, Koczulla R, Vogelmeier C, Kohnlein T, Welte T: The discovery of alphal-antitrypsin and its role in health and disease. Respir Med 2011;105:1129-1139.

51 de Serres FJ: Alpha-1 antitrypsin deficiency is not a rare disease but a disease that is rarely diagnosed. Environ Health Perspect 2003; 111:1851-1854.

52 Hersh CP, Dahl M, Ly NP, Berkey CS, Nordestgaard BG, Silverman EK: Chronic obstructive pulmonary disease in alphal-antitrypsin PI MZ heterozygotes: a meta-analysis. Thorax 2004;59:843-849.

53 Scott BB, Egner W: Does alpha1-antitrypsin phenotype PiMZ increase the risk of fibrosis in liver disease due to hepatitis $C$ virus infection? Eur J Gastroenterol Hepatol 2006;18: 521-523.

54 Perlmutter DH: Pathogenesis of chronic liver injury and hepatocellular carcinoma in alpha-1-antitrypsin deficiency. Pediatr Res 2006;60:233-238.

55 Schmechel DE, Browndyke J, Ghio A: Strategies for dissecting genetic-environmental interactions in neurodegenerative disorders. Neurotoxicology 2006;27:637-657. 
56 Schmechel DE: Art, alpha-1-antitrypsin polymorphisms and intense creative energy: blessing or curse? Neurotoxicology 2007;28: 899-914.

-57 Weiss G, Graziadel I, Urbanek M, Grunewald $\mathrm{K}$, Vogel W: Divergent effects of alpha 1-antitrypsin on the regulation of iron metabolism in human erythroleukaemic (K562) and myelomonocytic (THP-1) cells. Biochem J 1996;319:897-902.

- 58 Pandur E, Nagy J, Poor VS, Sarnyai A, Huszar A, Miseta A, Sipos K: Alpha-1 antitrypsin binds preprohepcidin intracellularly and prohepcidin in the serum. FEBS J 2009; 276:2012-2021.

-59 Hoffmann JA: The immune response of Drosophila. Nature 2003;426:33-38.

60 Ma Y, Li J, Chiu I, Wang Y, Sloane JA, Lu J, Kosaras B, Sidman RL, Volpe JJ, Vartanian T: Toll-like receptor 8 functions as a negative regulator of neurite outgrowth and inducer of neuronal apoptosis. J Cell Biol 2006;175: 209-215.

-61 Clardy SL, Wang X, Zhao W, Liu W, Chase GA, Beard JL, True Felt B, Connor JR: Acute and chronic effects of developmental iron deficiency on mRNA expression patterns in the brain. J Neural Transm Suppl 2006;71: 173-196.

62 Brunette KE, Tran PV, Wobken JD, Carlson ES, Georgieff MK: Gestational and neonatal iron deficiency alters apical dendrite structure of CA1 pyramidal neurons in adult rat hippocampus. Dev Neurosci 2010;32:238248.

63 Courchesne E, Karns CM, Davis HR, Ziccardi R, Carper RA, Tigue ZD, Chisum HJ, Moses P, Pierce K, Lord C, Lincoln AJ, Pizzo S, Schreibman L, Haas RH, Akshoomoff NA, Courchesne RY: Unusual brain growth patterns in early life in patients with autistic disorder: an MRI study. Neurology 2001;57: 245-254.
64 Duce JA, Tsatsanis A, Cater MA, James SA, Robb E, Wikhe K, Leong SL, Perez K, Johanssen T, Greenough MA, Cho HH, Galatis D, Moir RD, Masters CL, McLean C, Tanzi RE, Cappai R, Barnham KJ, Ciccotosto GD, Rogers JT, Bush AI: Iron-export ferroxidase activity of beta-amyloid precursor protein is inhibited by zinc in Alzheimer's disease. Cell 2010;142:857-867.

65 Lei P, Ayton S, Finkelstein DI, Spoerri L, Ciccotosto GD, Wright DK, Wong BX, Adlard PA, Cherny RA, Lam LQ, Roberts BR, Volitakis I, Egan GF, McLean CA, Cappai R, Duce JA, Bush AI: Tau deficiency induces parkinsonism with dementia by impairing APP-mediated iron export. Nat Med 2012; 18:291-295.

66 Rossner S, Ueberham U, Schliebs R, PerezPolo JR, Bigl V: The regulation of amyloid precursor protein metabolism by cholinergic mechanisms and neurotrophin receptor signaling. Prog Neurobiol 1998;56:541-569.

67 Haass C, Hung AY, Selkoe DJ: Processing of beta-amyloid precursor protein in microglia and astrocytes favors an internal localization over constitutive secretion. J Neurosci 1991; 11:3783-3793.

68 Hung AY, Koo EH, Haass C, Selkoe DJ: Increased expression of beta-amyloid precursor protein during neuronal differentiation is not accompanied by secretory cleavage. Proc Natl Acad Sci USA 1992;89:9439-9443.

69 Kirazov E, Kirazov L, Bigl V, Schliebs R: Ontogenetic changes in protein level of amyloid precursor protein (APP) in growth cones and synaptosomes from rat brain and prenatal expression pattern of APP mRNA isoforms in developing rat embryo. Int J Dev Neurosci 2001;19:287-296.

70 Sokol DK, Chen D, Farlow MR, Dunn DW, Maloney B, Zimmer JA, Lahiri DK: High levels of Alzheimer beta-amyloid precursor protein (APP) in children with severely autistic behavior and aggression. J Child Neurol 2006;21:444-449.
Ray B, Long JM, Sokol DK, Lahiri DK: Increased secreted amyloid precursor proteinalpha (sAPPalpha) in severe autism: proposal of a specific, anabolic pathway and putative biomarker. PLoS One 2011;6:e20405.

72 Sokol DK, Maloney B, Long JM, Ray B, Lahiri DK: Autism, Alzheimer disease, and fragile $\mathrm{X}$ : APP, FMRP, and mGluR5 are molecular links. Neurology 2011;76:1344-1352.

73 Connor JR, Menzies SL, St Martin SM, Mufson EJ: A histochemical study of iron, transferrin, and ferritin in Alzheimer's diseased brains. J Neurosci Res 1992;31:75-83.

74 Alizadeh BZ, Njajou OT, Millan MR, Hofman A, Breteler MM, van Duijn CM: HFE variants, APOE and Alzheimer's disease: findings from the population-based Rotterdam study. Neurobiol Aging 2009;30:330332.

75 Pankov R, Yamada KM: Fibronectin at a glance. J Cell Sci 2002;115:3861-3863.

\$6 Blystone SD, Graham IL, Lindberg FP, Brown EJ: Integrin alpha v beta 3 differentially regulates adhesive and phagocytic functions of the fibronectin receptor alpha 5 beta 1. J Cell Biol 1994;127:1129-1137.

-77 Lindbom L, Werr J: Integrin-dependent neutrophil migration in extravascular tissue. Semin Immunol 2002;14:115-121.

78 Porcionatto MA: The extracellular matrix provides directional cues for neuronal migration during cerebellar development. Braz J Med Biol Res 2006;39:313-320.

79 Gardiner NJ: Integrins and the extracellular matrix: key mediators of development and regeneration of the sensory nervous system. Dev Neurobiol 2011;71:1054-1072.

- 80 Beard JL, Felt B, Schallert T, Burhans M Connor JR, Georgieff MK: Moderate iron deficiency in infancy: biology and behavior in young rats. Behav Brain Res 2006; 170: 224-232. 